\title{
SISTEM INFORMASI HELPDESK TICKETING PADA PT. BANK MEGA Tbk
}

\author{
Rika Novita Wardhani ${ }^{1}$, Meinarini Catur Utami ${ }^{2}$, Ibnu Yahya Saputra ${ }^{3}$ \\ Politeknik Negeri Jakarta ${ }^{1}$ \\ Jalan Prof. DR. G.A. Siwabessy, Kukusan, Kecamatan Beji, Kota Depok, Jawa Barat 16424 \\ Universitas Islam Negeri Syarif Hidayatullah Jakarta ${ }^{2,3}$ \\ Jalan Ir H. Juanda No.95, Cemp. Putih, Kec. Ciputat, Kota Tangerang Selatan, Banten \\ 15412 \\ Sur-el : rika.novitawardahni@elektro.pnj.ac.id ${ }^{1}$, meinarini@ uinjkt.ac.id ${ }^{2}$, \\ ibnu.saputra13@mhs.uinjkt.ac.id ${ }^{3}$
}

\begin{abstract}
PT Bank Mega Tbk is a private company that focuses on banking. Computerized helpdesk ticketing system is needed to support activities at PT. Bank Mega Tbk, due to improve services in making a complaint report on the problem to be solved. The large number of complaints that enter the IT Support section is not optimal because the other units do reporting using many communication channels without any clear communication lines so there is no recording process, and frequent data redundancies. Therefore, from the above problems the authors try to make an analysis and design of an information system for helpdesk ticketing that can help IT Support staff. The system design is refers to the Rapid Application Development (RAD) model and for a tool using UML (Unified Modeling Language). With the design of this system, it is expected to help solve the problems.
\end{abstract}

Keywords: Information System, Helpdesk Ticketing, Rapid Application Development, Unified Modelling Language

\begin{abstract}
Abstrak : PT Bank Mega Tbk merupakan perusahaan swasta yang berfokus pada perbankan. Helpdesk ticketing system yang terkomputerisasi sangat diperlukan untuk menunjang kegiatan di PT. Bank Mega Tbk, dalam membuat laporan keluhan masalah yang ingin diselesaikan. Banyaknya jumlah keluhan yang masuk di bagian IT Support, penanganannya tidak optimal karena para unit lain melakukan pelaporan menggunakan banyak jalur komunikasi tanpa adanya jalur komunikasi yang jelas sehingga tidak adanya proses pencatatan, meskipun permasalahan dapat diselesaikan namun memakan waktu yang lama dan sering terjadinya redundasi data. Dari permasalahan diatas penulis mencoba membuat analisis dan perancangan sistem informasi helpdesk ticketing system yang dapat membantu staf IT Support. Rancangan sistem dibuat dengan mengacu model pengembangan Rapid Application Development (RAD) dan tool untuk perancangan sistem menggunakan UML (Unified Modelling Language). Adanya perancangan sistem ini, diharapkan dapat membantu menyelesaikan permasalahan.
\end{abstract}

Kata kunci: Sistem Informasi, Helpdesk Ticketing, Rapid Application Development, Unified Modelling Language

\section{PENDAHULUAN}

Salah satu perusahaan yang dalam menjalankan prosesn bisnisnya mengembangkan dan menerapkan teknologi informasi adalah PT. Bank Mega Tbk, yang mana merupakan salah satu perusahaan swasta yang berfokus pada sektor perbankan. Memberi pelayanan terbaik yang didukung dengan teknologi informasi yang tepat dan meningkatkan kinerja perusahaan merupakan salah satu faktor penting yang harus diperhatikan. Untuk meningkatkan pelayanan perusahaan dibutuhkan teknologi informasi pendukung yang mendorong terbentuknya web application yang dapat menunjang kebutuhan informasi dan user friendly. Dimana teknologi 
informasi pendukung ini menjadi alat bantu yang dapat digunakan oleh semua pihak terkait.

Helpdesk ticketing system adalah layanan teknologi informasi berupa support/maintenance dan berisikan laporan permintaan bantuan, masalah yang menyangkut maintenance IT yang dihadapi kantor pusat dan kantor cabang (Koneksi, PC rusak dll), yang dibuat untuk memuat keluhan-keluhan seluruh pegawai di kantor pusat dan cabang secara tersusun. Sesuai dengan kebijakan tata kelola IT mengacu pada Direktorat Kemanan Informasi (2011) tentang pengamanan informasi harus mencakup sekurangkurangnya terdapat prosedur pengendalian dokumen, prosedur pengendalian rekaman, prosedur tindakan perbaikan dan pencegahan, prosedur penanganan informasi, prosedur penanganan insiden, dan prosedur pemantauan penggunaan fasilitas teknologi informasi [1], maka helpdesk ticketing system merupakan salah satu penunjang tata kelola IT yang baik dalam suatu perusahaan.

Helpdesk ticketing system untuk menunjang aktivitas kinerja perusahaan agar dapat berjalan dengan baik, tanpa adanya masalah aktivitas kinerja karyawan dalam melakukan perkerjaan dan dengan adanya helpdesk ticketing system karyawan dapat melakukan pengaduan masalah seperti yang telah disampaikan oleh Qoyyimah (2011) dimana rancang bangun helpdesk ticketing yang dibuatnya membuat laporan pengaduan yang masuk dapat dicatat sistematis dan tidak ada data redundan [2]. Helpdesk ticketing juga dapat merekomendasikan peralatan atau komputer lama ke baru serta dapat digunakan sebagai sarana untuk memberikan layanan bantuan kepada seluruh civitas bank pusat maupun bank cabang dan membantu terlaksananya kegiatan unit kerja yang ada, seperti halnya yang dilakukan oleh Setiyorini dan Irawan (2017) yang mana dengan penambahan Knowledge Management System (KMS) dapat memudahkan pertukaran pengetahuan antar divisi [3].

Menurut Jogiyanto (2008), sistem merupakan sekumpulan prosedur yang saling berkumpul dan saling berhubungan untuk menyelesaikan suatu kegiatan [4]. Informasi bisa dinyatakan sebagai suatu data yang bisa ditarik kesimpulan [5]. Sehingga Sistem Informasi bisa disimpulkan bahwa sekumpulan prosedur yang salaing berhubungan dan bekerjasama untuk menyelesaikan suatu kegiatan dengan mengolah data hingga menjadi suatu informasi yang bermanfaat. Sistem Informasi merupakan salah satu alat yang bisa memberikan informasi akurat menurut Kadir seperti yang disampaikan oleh Wahyuni [6].

Menurut Syukriah (2007) yang dikutip oleh Mediana [7], helpdesk system merupakan suatu sistem yang digunakan untuk menyelesaikan suatu masalah pada suatu perusahaan, dimana untuk menyelesaikan tersebut memerlukan sistem ticketing untuk dapat mendata incident ataupun permasalahan yang disebabkan oleh IT services perusahaan sehingga dapat teridentifikasi dan dikonsolidasikan melalui berbagai media komunikasi yang tersedia di perusahaan, seperti telepon, email, dan juga web interface. Sedangkan seseorang yang bertugas untuk melayani permasalahan tersebut disebut dengan service desk, yang mana orang tersebut merupakan seseorang dari Departemen Teknologi Informasi (DTI) yang berperan sebagai single point of contact untuk berkaitan langsung dengan pengguna, serta departemen terkait pelayanan. Melalui helpdesk, data 
terpusat dapat tersajikan dari semua permasalahan sehingga setiap informasi informasi tersebut dapat digunakan untuk meningkatkan pelayanan dan ketersediaan sistem. Informasi tersebut juga dapat digunakan juga untuk mendukung perbaikan, upgrade atau perubahan dalam infrastruktur teknologi informasi. Ticketing adalah Sebuah karcis ganguan (kadang-kadang disebut laporan masalah) adalah mekanisme yang digunakan dalam suatu organisasi untuk melacak deteksi, pelaporan, dan resolusi dari beberapa jenis masalah. Trouble sistem Ticketing berasal dari manufaktur sebagai dasar sistem pelaporan kertas, sekarang kebanyakan berbasis web dan terkait dengan hubungan manajemen pelanggan (CRM) lingkungan, seperti call center atau $e$ business [8].

Bank secara sederhana dapat diartikan sebagai lembaga keuangan dimana kegiatan utamanya adalah menghimpun dana dari masyarakat serta menyalurkan kembali dana tersebut ke masyarakat serta memberikan jasa bank lain [9].

Berdasar kepemilikan, pengelompokan bank dinataranya terdiri atas [10] :

a. Bank milik pemerintah yaitu bank yang akte pendirian dan modalnya dimiliki oleh pemerintah. Contoh : BNI, Bank Mandiri, BRI, BTN.

b. Bank milik swasta nasional yaitu bank yang seluruh atau sebagian besar modalnya dimiliki oleh swasta nasional atau akte pendiriannya didirikan oleh swasta sehingga pembagian keuntungan juga ke pihak swasta. Contoh : Bank Mega, Bank Danamon, Bank Bukopin.
Proses pengolahan helpdesk ticketing pada PT. Bank Mega masih manual dalam melakukan perkerjaan, karena sistem helpdesk ticketing yang belum terkomputerisasi sehingga berjalan tidak optimal, seperti pelaporan menggunakan banyak jalur komunikasi dengan tanpa adanya jalur komunikasi yang jelas, sehingga tidak adanya proses pencatatan, meskipun permasalahan dapat diselesaikan namun memakan waktu yang lama karena dilakukan secara manual sehingga proses tidak terkontrol dan sering terjadinya redundansi data. Dengan melihat perkembangan teknologi yang pesat dan sangat diperlukan di suatu perusahaan, maka sebaiknya sistem helpdesk ticketing Bank Mega dibagun dengan berbasis web.

\section{METODOLOGI PENELITIAN}

Metodologi penelitian ini berisikan teori yang berkaitan dengan Sistem Informasi, Helpdesk Ticketing, Perbankan sebagai objek penelusuran, serta langkah-langkah metode dan tool dalam membuat rancangan Helpdesk Ticketing yaitu model Rapid Application Development (RAD) dan tool Unified Modelling Language (UML).

\subsection{Model Rapid Application Modelling (RAD)}

Metode yang digunakan dalam pembuatan perangkat lunak pada penelitian ini menggunakan model Rapid Aplication Development (RAD) [11]. Fase-Fase dalam RAD Model, yaitu :

1) Requirement Planning, mengidentifikasi tujuan sistem yang akan dirancang dan 
mengidenfikasi kebutuhan informasi tujuan yang akan dibuat.

2) Workshop Design, membuat pemodelan pada aplikasi baru yang dapat mewakili sistem yang berjalan saat ini di Helpdesk PT. Bank Mega.

3) Implentation, fase yang terakhir ini adalah fase untuk memperkenalkan sistem yang telah dibuat oleh penulis untuk pengguna (user) dapat dilihat dan dipelajari lebih mendetail. Dan akan diberikan testing khusus untuk implementasi sistem tersebut.

\subsection{Tool Unified Modelling Language (UML)}

UML (Unified Modeling Language) adalah salah satu alat bantu yang sangat handal di dunia pengembangan sistem yang berorientasi objek. Hal ini dikarenakan UML menyediakan bahasa pemodelan visual yang memungkinkan bagi pengembang sistem untuk membuat cetak biru atas visi mereka dalam bentuk yang baku, mudah dimengerti serta dilengkapi dengan mekanisme yang efektif untuk berbagi (sharing) dan mengkomunikasikan rancangan mereka dengan yang lain [12].

\subsection{Tahapan Penelitian}

Gambar 1 merupakan alur penelitian yang merupakan wujud dari tahapan metodologi

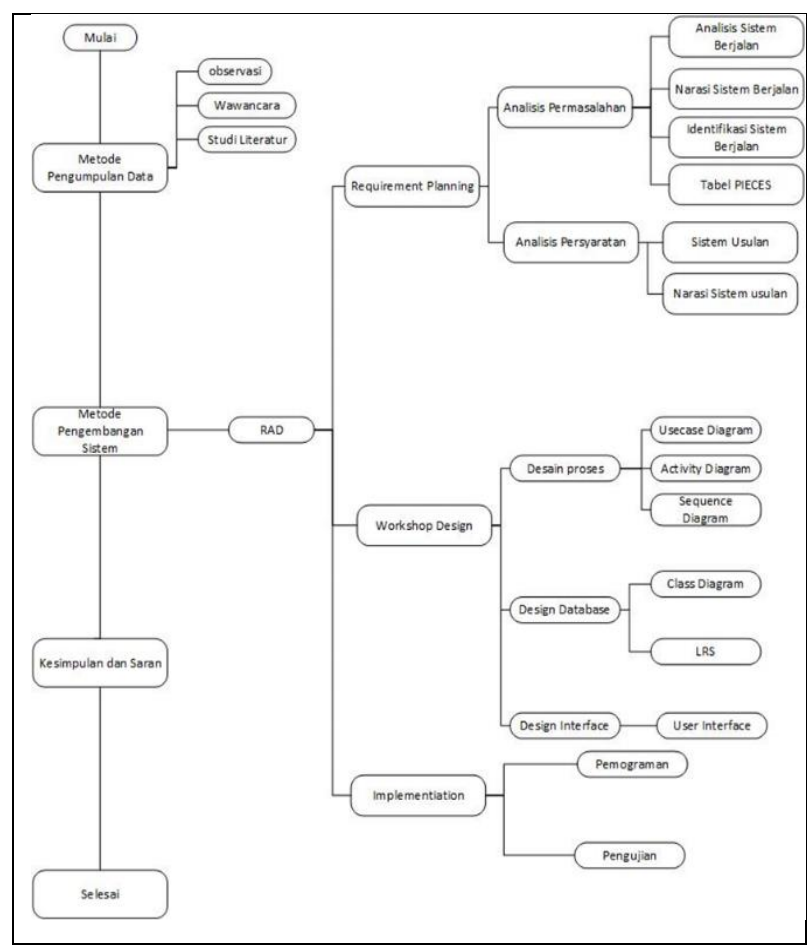

Gambar 1. Tahapan Penelitian

\section{HASIL DAN PEMBAHASAN}

Pada bagian ini akan ditampilkan beberapa tampilan hasil rancangan sistem informasi helpdesk ticketing. Gambar 2 merupakan halaman kelola tiket yang mana pengguna yang mempunyai hak akses sebagai operator bisa melakukan kelola ticket.

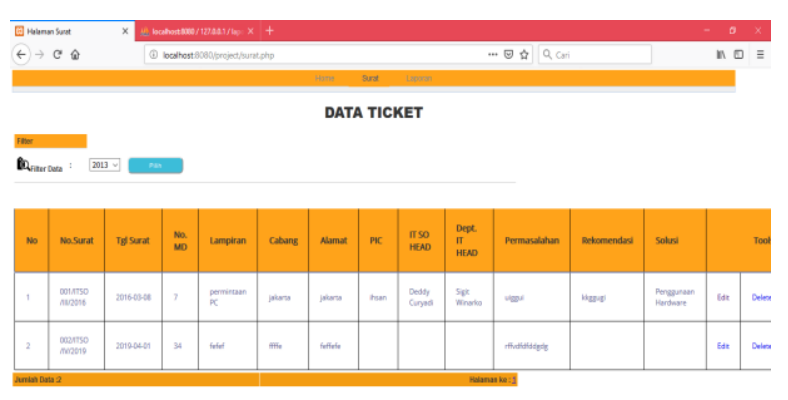

Gambar 2. Halaman Kelola Tiket

Selanjutnya gambar 3 merupakan halaman dimana pengguna yang memiliki hak akses seperti unit lain bisa input ticket. 


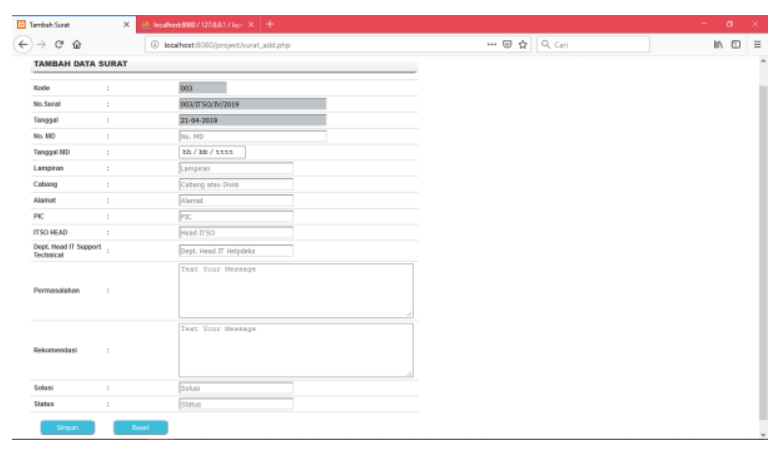

Gambar 3. Halaman Input Tiket Operator

Halaman view tiket status seperti yang terlihat pada gambar 4 dapat diakses oleh unit lain, untuk melihat status tiket yang dilaporkan.

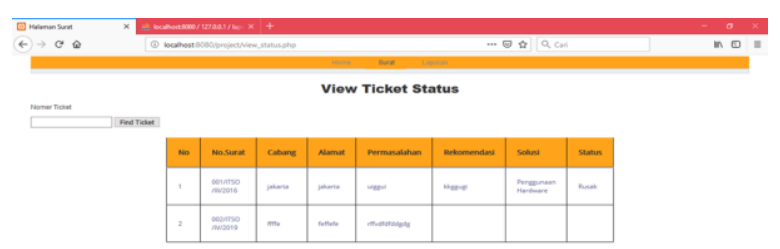

\section{Gambar 4. Halaman View Tiket Status}

Halaman input tiket unit lain seperti yang terlihat pada gambar 5 dapat diakses oleh unit lain, untuk menginput data ticket melalui helpdesk ticketing dan mendapatkan nomer.

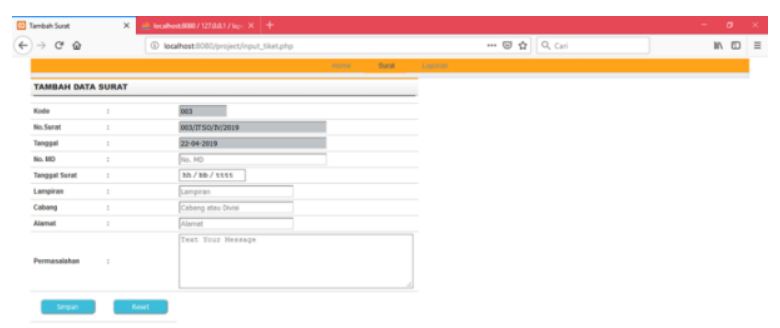

Gambar 5. Halaman Input Tiket Unit Lain

Halaman update status tiket seperti yang terlihat pada gambar 6 dapat diakses oleh teknisi, untuk mengupdate problem data ticket yang diinput oleh unit lain.

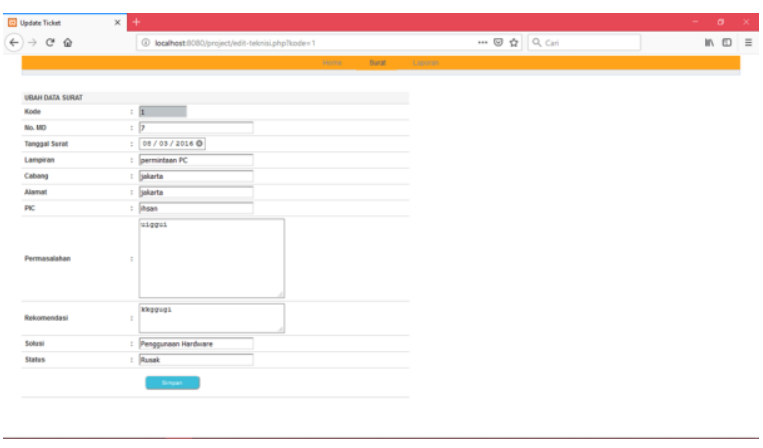

Gambar 6. Halaman Update Status Tiket

Halaman input tiket operator seperti yang terlihat pada gambar 7 dapat diakses oleh operator untuk menginput data ticket yang dilaporkan oleh unit lain melalui telp, whatsapp dan email.

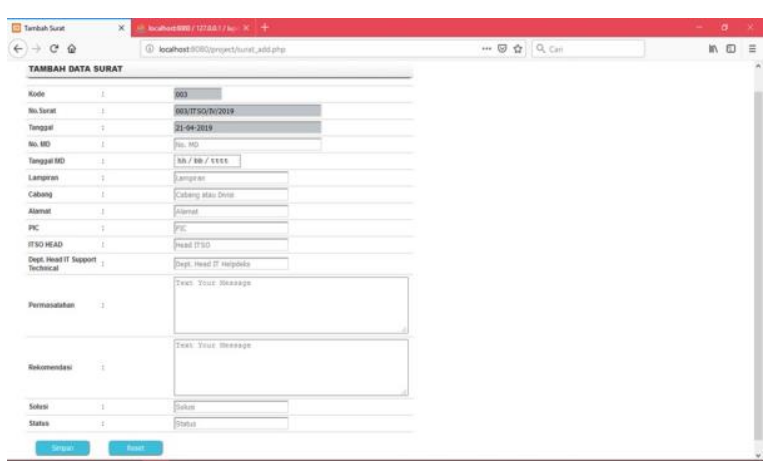

Gambar 7. Halaman Input Tiket Operator

Halaman manage user seperti yang terlihat pada gambar 8 dapat diakses oleh operator untuk melihat data user yang sudah diinputkan atau untuk menambah dengan input data user baru.

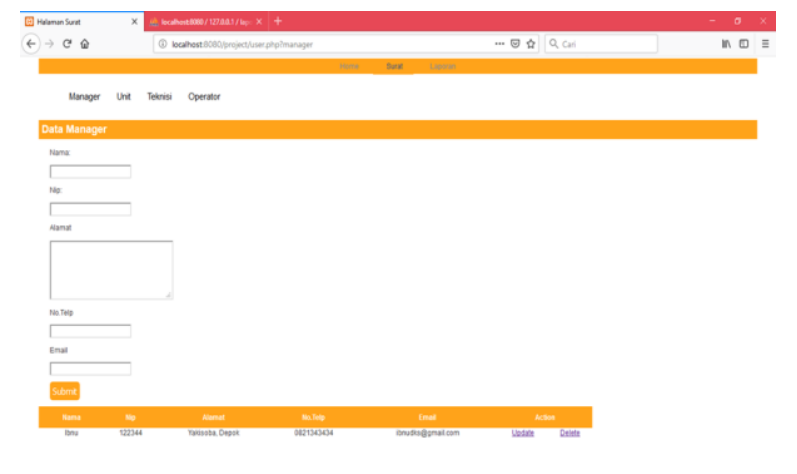

Gambar 8. Halaman Manage User 
Halaman user interface operator seperti yang terlihat pada gambar 9 dapat diakses oleh operator, manajer, unit lain dan teknisi untuk melihat menginputkan/melihat data tiket.
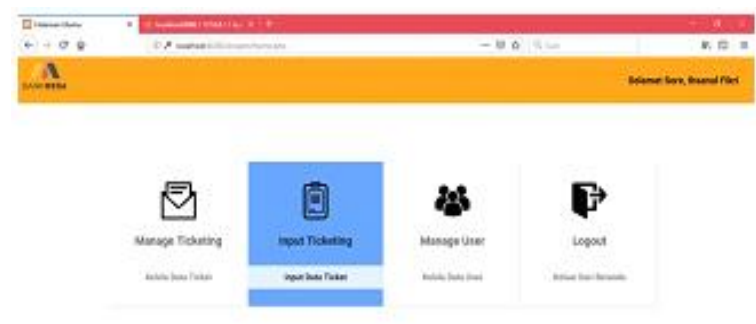

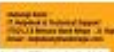

\section{Gambar 9. Halaman User Interface Operator}

Halaman ticket report seperti yang terlihat pada gambar 10 dapat diakses oleh manajer untuk melihat hasil laporan data ticket per periode.

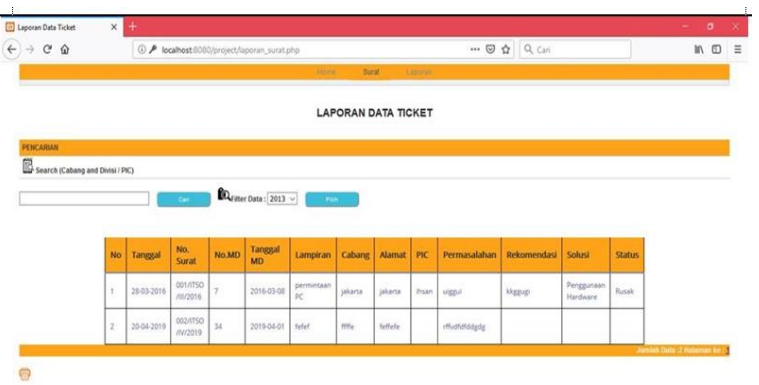

\section{Gambar 10. Halaman Ticket Report}

\section{KESIMPULAN}

Berdasarkan pembahasan yang telah dilakukan, maka diperoleh beberapa kesimpulan:

1) Pencatatan masalah dapat dilakukan secara sistematis, sehingga data aman dan akurat dengan tidak adanya data yang duplikasi. Dengan adanya Helpdesk Ticketing System, maka tugas kepala divisi IT Support lebih terkomputerisasi dalam melihat laporan bulanan permasalahan yang dialami Unit lain, baik masalah koneksi jaringan internet maupun kerusakan hardware.

2) Terkontrolnya proses dalam memperbaiki keluhan Unit lain dan penanganan kerusakan hardware terkoodinasi dengan baik.

3) Dengan adanya sistem helpdesk ticketing akan mempermudah staff helpdesk dalam mengerjakan laporan masalah dari Unit lain, pengeolahan data, serta penyimpanan data.

\section{DAFTAR PUSTAKA}

[1] Saputra, D., Gilang H, O. Evaluasi Keamanan Informasi Pada SMA Al-Azhar (SMAIA) 4 Kemang Pratama Berdasarkan Indeks Keamanan Informasi (KAMI) SNI ISO/IEC 27001:2009. Jurnal Khatulistiwa Informatika, 4 (1), 2016.

[2] Qoyyimah, Hidayah, N.A., Fananie, Z.B. Rancang Bangun Helpdesk Ticketing System (Studi Kasus : PT. Primus Indojaya). Jurnal Sistem Informasi : Studia Informatika, 5(1). 2012.

[3] Irawan, A., Setyorini, N.K. Rancang Bangun Aplikasi Helpdesk Dengan Menggunakan Pendekatan Knowledge Management System Pada Seksi Teknisi PT. Indah Kiat Pulp \& Paper Tbk. Jurnal ProTekInfo, 4. 2017

[4] Jogiyanto. Metodologi Penelitian Sistem Informasi. CV Andi Offset. Jogjakarta. 2008

[5] Mulyanto, A. Sistem Informasi Konsep dan Aplikasi. Pustaka Pelajar. Jogjakarta. 2009

[6] Wahyuni, H.C., Astuti, M. Sistem Informasi Berbasis Android Untuk RW 5 Desa Gelam, Candi, Kabupaten Sidoarjo. Jurnal JABDIPAMAS, 2 (2). 2018

[7] Mediana, D., Nurhidayat, A.I. Rancang Bangun Aplikasi Helpdesk (A-Desk) Berbasis Web Menggunakan Framework Laravel (Studi Kasus di PDAM Surya Sembada Kota Surabaya).

[Online]

Avalaible

https://jurnalmahasiswa.unesa.ac.id/inde x.php/jurnal-manajemen- 
informatika/article/viewFile/24298/2222

4 [Accessed: 26-April-2020]

[8] Rouse, M. Trouble Ticket (Troubel Report). [Online]

Available:

https://searchcustomerexperience.techtar get.com/definition/trouble-ticket-troublereport [Accessed: Juli-2019]

[9] Kasmir. Bank dan Lembaga Keuangan Lainnya. Raja Glasindo Persada. Jakarta. 2003

[10] Taswan. Manajemen Perbankan, Konsep, Teknik dan Aplikasi. UPP. Jogjakarta. 2010

[11] Rosa A.S, \& Shalahuddin, Rekayasa Perangkat Lunak Struktur dan Berorientasi Objek. Informatika. Bandung 2014.

[12] Munawar. Pemodelan Visual Dengan UML. Graha ilmu. Jakarta. 2017 